\title{
HOW TO BE A NATION OF MIGRANTS? A RETURN TO ROOTS VERSUS GLOBAL CITIZENSHIP IN CONTEMPORARY MAURITIAN POETRY
}

\author{
Aleksandra NOCOŃ (University of Silesia, Katowice) \\ ORCID: 0000-0003-2823-4039
}

\section{Introduction}

Before the colonial period, Mauritius was an uninhabited island situated in the Indian Ocean, more than a thousand kilometres from Madagascar. Discovered by the Portuguese, then colonialized consecutively by the Dutch, the French and the British, the so-called Paradise Island has become a homeland for African slaves, Indian coolies and Chinese labourers. This potpourri of three races speaking approximately eighteen languages makes Mauritius an absorbing subject for cultural and linguistic studies.

My research is focused on contemporary Mauritian poetry, by which I mean the poems written in the second half of the $20^{\text {th }}$ century and in the past two decades of the $21^{\text {st }}$ century. Despite the fact that for over 150 years English has been the main language of administration and education, poetry remains primarily francophone due to historical conditioning. Mauritian literature was born in French-speaking Creole circles, and the language of Molière is still associated with upper echelons, culture and artistic creativity. However, many authors who have acquired their higher education in the United Kingdom come to a decision to express themselves in English, among them a significant part of the young generation (born in the 1990s and later).

As the theme of problematic migrant condition is apparently crucial for Mauritians, a depiction of all attitudes goes beyond the prospect of a single essay. My aim would be therefore to present three groups of contemporary poets who try to cope with the 
subject of island identity. I am going to show the principal differences between the old and the rising generation through the lens of poetry by focusing on three dimensions: their attitude to the motherland, to postcolonial topics and to migration.

Nevertheless, before hitting the high points, it seems necessary to indicate some historical factors that have shaped the current literary tendencies.

\section{Historical and Cultural Background}

The francophone literature of Mauritius was born at the end of the eighteenth century due to a conjunction of many factors, among which the most significant are: (a) the introduction of printing offices; (b) the establishment of societies of writers and intellectuals; (c) the publication of texts about Mauritius by European travellers which roused Mauritian readers to anger. Thanks to the printing houses, the FrancoMauritians and the Creoles (descendants of white colonizers and African or Malagasy slaves) were able to express their discontent and, naturally, they did it in French.

Although British domination was introduced shortly after (1810), it did not have a great impact on the language matter, since according to the act of capitulation, the settlers were allowed to preserve their religion, law and customs. The use of French was thought to be one of these customs, so English was not even taught at schools for thirty years. What is more, the Indian immigrants learned to speak Creole, the specific language of the Island based on French, which is used at present by $90 \%$ of the population. English remained for a long time the language of administration and official education. It is only nowadays, in the time of the global village and English becoming the lingua franca of our times, that Mauritian writers began to appreciate its usefulness in spreading their ideas around the world.

In the nineteenth century, francophone Mauritian poetry was inspired mainly by parnassianism and the researchers agree that Léoville L'Homme (1857-1928) should be ranked as its best representative. The "father of Mauritian poetry" manifested a kind of idolatrous admiration towards French culture which was later named "francotropisme" by Jean-Georges Prosper, a literary scholar specializing in Mauritian literature. At the time, the waves of migration from India occasioned the anxiety of Creoles who feared being submerged by these new social strata, thus they tried to differentiate themselves by emphasizing their adherence to the French cultural milieu. L'Homme's poetry excels in noble and idealistic language, frequently finding shelter in abstraction and mythology. What is remarkable is that he paved the way toward the literature that better reflects the richness and polyphony of Mauritian society.

Nonetheless, Joubert argues that L'Homme, a victim of the old form, was limited by the social, racial and political affiliations he could not readily abandon. ${ }^{1}$ In these terms he is quite the countertype of contemporary poets who transgress the borders of their own affiliations in search of truth and beauty.

The poet who succeeded in breaking with alexandrine and other markers of Parnassian aesthetics was Robert-Edward Hart (1891-1954). Not only did he introduce free verse on the Island, but he also proclaimed his will of being a Mauritian poet, a will originating from his love of Mauritian scenery and a fairy-tale like childhood. As we will see later, many poets followed his example.

Naturally, these two personalities do not resume the poetic creation that had existed in Mauritius before the Second World War. They were supposed to show the evolution (and some continuity, too) of poets' attitudes towards their native island. After the war,

\footnotetext{
${ }^{1}$ Jean-Louis Joubert, Littératures de l’océan Indien (Paris: Vanves, 1991), 119.
} 
the process accelerates. Mauritian literature ceases to be the domain of French Mauritians and a few Creoles as the Paradise Island discovers itself and assumes its cultural plurality. There is a need to define Mauritian specificity in the intermingling of original cultures, rather in the perspective of the Indian Ocean than in relation to fardistant France. ${ }^{2}$ Taking into account the emigration factor, due to the development of the airline industry Mauritius becomes less isolated. Many citizens move out and some of the exiles choose literature as their way back to the island.

By this somewhat reduced historical survey, we come to our times and to contemporary poetry. ${ }^{3}$ Hopefully, this background proves useful in understanding the character of Mauritian culture and the meanders of the search for its identity.

\section{Three Groups of Poets}

There is a broad range of contemporary Mauritian authors whose attempts to find or define their identity are reflected in their poetry. For the purpose of comparison I have arranged them into three groups, although it should be mentioned that they are not totally homogeneous. Nevertheless, each of them has a different approach towards the migrant condition. In order to help the reader to navigate efficiently through all the unfamiliar surnames, I present them in the table below:

Table 1: Three generations of Mauritian poets

\begin{tabular}{|l|l|l|}
\hline \multicolumn{2}{|c|}{ Mauritian poets born in: } \\
\hline \multicolumn{1}{|c|}{$1930-1968$} & \multicolumn{1}{|c|}{$1969-1989$} & after 1990 \\
\hline Edouard Maunick *1931 & Sylvestre Le Bon *1969 & Ameerah Arjanee *1994 \\
Vinod Rughoonundun *1955 & Anil Rajendra Gopal *1970 & Aqiil Gopee *1997 \\
Khal Torabully *1956 & Yusuf Kadel *1970 & Lisa Ducasse *1997 \\
Sedley Richard Assonne *1961 & Umar Timol *1970 & \\
Michel Ducasse *1962 & Stefan Hart de Keating *1971 & \\
Thierry Château *1963 & Alex Jacquin-Ng*1973 & \\
& & \\
& & \\
\end{tabular}

\footnotetext{
${ }^{2}$ Cf. Vicram Ramharai, "Entre littérature mauricienne et littérature francophone: quels enjeux pour les écrivains mauriciens ?," E-France: an on-line Journal of French Studies, vol. 2 (2008), 20.

${ }^{3}$ For more details see also: Jean-Georges Prosper, Histoire de la littérature mauricienne de langue française (Port-Louis: Éditions de l'Océan Indien, 1994) or Vicram Ramharai, "Le champ littéraire mauricien," Revue de littérature comparée, avril-juin (2006).
} 
The first group is comprised of members born before Mauritius obtained independence (which was in 1968). According to Krzysztof Jarosz, poets like Edouard Maunick, Khal Torabully, Sedley Richard Assonne or Michel Ducasse confront the colonial past and fight racism, having a tendency for a certain martyrology. ${ }^{4}$ Moreover, the oldest of this group eagerly use the opportunity to expatiate on Mauritius' multiculturalism, local art, climate and customs, employing either a traditional lyrical register (M. Ducasse and Vinod Rughoonundun) or an anti-exotic and acrid one (Assonne). Additionally, some of them have an inclination for nostalgic reminiscence of the Island which is reflected in poetical description of its landscapes. That current is represented by Maunick and Rughoonundun.

Another group, the generation from the late 1960s and the early 1970s, generally prefers to concentrate on the present day, trying to fit into multicultural society and cope with the difficulties of multilingualism. The inclination to glorify the botanical gorgeousness and idyllic side of the Island is also visible (especially in Sylvestre Le Bon's and Anil Gopal's work), but no more than some realistic constatations about the exploitation of the poorest and other drawbacks of Mauritian democracy, described incisively by Umar Timol. Nonetheless, the overall poetical tendency is to search the depths of one's conscience and identity, either by means of deliberate meditations (like those of A.R. Gopal, Stefan Hart de Keating or Yusuf Kadel) or through a ferocious hunt (of Timol and Alex Jacquin-Ng). ${ }^{5}$

The youngest poets, born after 1990, break with the past and become citizens of the world. It is hard to find any references to mauritianity in Lisa Ducasse's or Aqiil Gopee's poetry, which could suggest that they are not obsessed with the identity quest. The rising generation tends to focus on their inner life, apparently looking for their own poetical narration. Since they draw inspiration from travels and books from all over the world, they likely find more points of reference to the global village than to their ancestors' rough experiences. Another common denominator of this assemblage is the language shift: Ameerah Arjanee writes exclusively in English. L. Ducasse, despite her francophone parents (M. Ducasse et Shenaz Patel, also writers), published her first poetry collection under an English title: Midnight Sunburn and 17 footsteps, where out of eighteen texts only five are in French. As regards Gopee, his poems are admittedly in French, but with English headings. The above manifestations of focusing on more current, universal experiences accord with a statement by Sachita Samboo, a Mauritian researcher, who notes, in reference to contemporary literary production, that one can observe a greater interest in English, especially in poetry. ${ }^{6}$ She also perceives the newest poetry as more lighthearted and less concerned about the past. By extension, this would be the third group of Mauritian poets: global citizens writing in English about universal human experiences.

As noted above, each of these groups takes a different view of cultural notions like motherland, migration, expatriation or postcolonialism, while also adopting a different perspective on their identity and heritage. I am therefore going to compare and contrast

\footnotetext{
${ }^{4}$ Krzysztof Jarosz, "Brzmienie tęczy. O współczesnej francuskojęzycznej poezji Mauritiusa," Opcje 3 (2016): 156.

${ }^{5}$ Cf. Jean-Louis Joubert, "La poésie mauricienne d'aujourd'hui," Francofonia 48 (2005): $126-131$.

${ }^{6}$ Anna Szkonter-Bochniak, L'analyse des personnages principaux dans les romans d'Ananda Devi a la lumière du modèle théorique de l'effet-personnage de Vincent Jouve, Ph.D. thesis (Katowice: Wydawnictwo Uniwersytetu Śląskiego, 2018), 64.
} 
selected poems of each group in order to present the main differences between them and outline current contradictive tendencies.

\section{Motherland}

Let us begin with a comparison of attitudes to Mauritius, the motherland of all the above mentioned authors. As most texts are French and have not yet been translated, I propose my own philological translation, with the proviso that it is the most literal version created for the readers unfamiliar with French just to make the meaning clear. It disregards the nuances of form, rhyme and most importantly, rhythm, which, incidentally, is a significant component of Mauritian poetry.

The first text was written by Maunick, a living legend of Mauritian poetry. He left the Paradise Island in 1960 (at the age of 29) and moved to Paris. Apart from having published more than twenty books of poetry and having received the Grand Prix de la francophonie, he was also a contributor to the journal Présence Africaine, a member of UNESCO and the Mauritian ambassador to South Africa. His poetry often conveys feelings of isolation, as in the following passage:

Original text

\section{$[\ldots]$}

je m'accuse d'avoir déserté ma ville fétiche comme l'on cherche à se saborder / censé coupable d'être resté à quai trop longtemps / sans jamais ne prendre le large / alors que chaque soir je jouais à passer le dernier amer / la douane de tous les clandestins / sans avoir payé d'octroi / avec pour seuls papiers

mes premiers poèmes plein la tête /

vagabond sans voyages pris

en flagrant délire d'exil

\section{$[\ldots]$}

ai-je vraiment déserté / seule ma parole répond combien ELLE est nue / combien ELLE brûle /

combien ELLE perdure / quand même combien

la vague refuse de retourner le sablier

ELLE! NEIGE! la mer! l'enfance! la mer!...?
Philological translation

\section{$[\ldots]$}

I accuse myself of having deserted my fetish city

like we seek to sink ourselves / supposed guilty of having waited too long on the platform

never to set out / while

every evening I acted I passed the last bitter / the customhouse of all clandestines / without paying excise / with for only papers my first poems head full / vagabond without travelling in flagrante delirium of exile

\section{$[\ldots]$}

have I really deserted / only my words respond how SHE is naked / how SHE burns /

how SHE endures / even how the wave refuses to give back the sandglass

SHE! SNOW ! the sea! the childhood! the sea!

${ }^{7}$ Edouard Maunick, "Elle," in Anthologie de la poésie Mauricienne contemporaine d'expression Française, ed. Yusuf Kadel (Paris: Acoria, 2014), 106-107. 
The poem is very polysemic, as the eponymous pronoun - she - can refer to the city, the sea, the woman or to childhood. Nevertheless, it is always about the Island and tangled feelings of longing, love, nostalgia and remorse.

Another poem about the city is entitled Je suis entré dans la ville (I entered the city) and it shows quite a different perspective of the younger (by 32 years) poet, Thierry Château:

Original text

$[\ldots]$

Et ça a continué ainsi

D'année en année

De chocs en chocs

D'émerveillement en dégoût

De l'amour à la haine

Il n'y a qu'un pas ${ }^{8}$
Philological translation

$[\ldots]$

And it kept on like this

Year by year

Shock by shock

From wonder to disgust

From love to hatred

There is only one step

Château describes his bond with Port-Louis, the capital of Mauritius, as a constantly developing lovers' relation. Despite the age differences and the evident flaws of this relationship, he remains faithful to the Island. He is one of many poets praising Mauritian traditions, multiculturalism, and women's beauty.

By contrast, Arjanee, a young Mauritian poetess who studies in Madrid, is not so eager to overlook the flaws of her motherland:

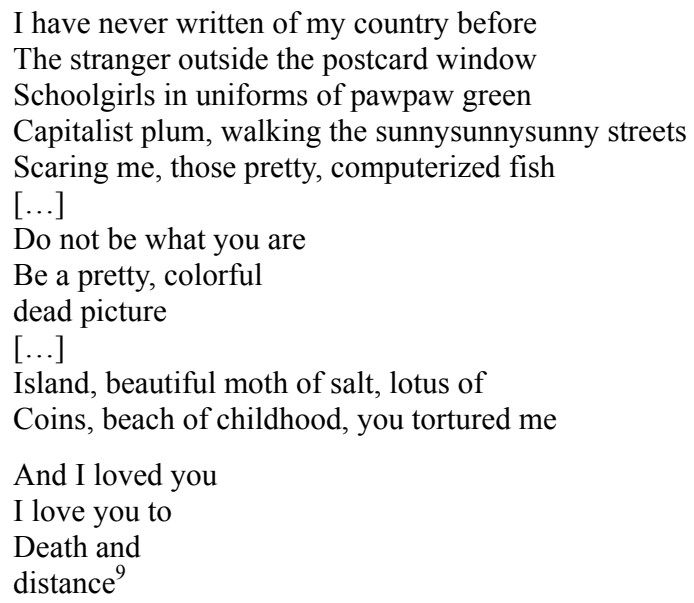

Of course, criticizing the Paradise Island is not the domain of young poets, but they are the first to look at their country with a certain distance. Older emigrants, like Maunick or Torabully, are constantly returning to Mauritius (on paper, at least) with memories, passion, disappointment, nostalgia and a wide range of other feelings. Arjanee, on the contrary, observes the less-than-stellar Mauritian community and immediately

\footnotetext{
${ }^{8}$ Thierry Château, "Je suis entré dans la ville," in Anthologie de la poésie Mauricienne contemporaine d'expression Française, ed. Yusuf Kadel (Paris: Acoria, 2014), 33.

${ }_{9}$ Ameerah Arjanee, Morning with my Twin Sister and other poems (Trou d'Eau Douce: L'Atelier d'écriture, 2014), 114.
} 
distances herself with a highly ironical description. She cannot reject her love for her country, but she can stay away from it just as one does in the case of a toxic relationship.

Does it mean that the rising generation will lose their national identity? It seems not. Although the affairs of the motherland are no longer brought to the foreground, the young poets care about their motherland and do not intend to disavow it. As evidence thereof let us turn to the words of L. Ducasse, who thought it indispensable to present her first poetry collection in Mauritius after promoting it in Paris. She said to a journalist, "Il fallait que je puisse revenir afin de le permettre de s'envoler d'ici. Parce que c'est ici qu'il naît et qu'il prend racine." ${ }^{\prime 10}$ (I had to come back in order to let it take off from here. Because this is where it is born and where it takes root). Apparently, the young generation wants to be cosmopolitan without becoming denationalized. Whether they meet the challenge is another matter.

What about the generation born in the 1960s and the 1970s? They are apparently still focused on Mauritius and torn between affirmation and dismay. While Le Bon praises the magical moments of beautiful Creole women dancing sega on the beach, ${ }^{11}$ Assonne complains about the fake image of his hypocrite island, upheld for the tourists. ${ }^{12}$ A fragment from Umar Timol's poem entitled L'Amicale (Society of Friends) is particularly noteworthy in this regard, as it illustrates another dimension of critical reflection concerning the Paradise Island, namely a swipe at the citizens' shameful behaviour towards their homeland:

Original text

Mon pays mon pays

tu es désormais un dépotoir

on vomit sur tes ennuis des cataclysmes

de haine

$[\ldots]$

mon pays mon pays

ta raison fout le camp

tu te désagrèges

île-beauté, île-paradis

t'es désormais île-anarchie, île-poubelle

$[\ldots]$

mon pays mon pays

tu te meurs ${ }^{13}$
Philological translation

My country my country

You are now a junkyard

We vomit on your troubles with cataclysms

of hatred

[...]

my country my country

your reason gets the hell out of here

you are falling apart

island-beauty, island-paradise

you are now island-anarchy, island-dumpster

[...]

my country my country

you are slowly dying

Despite the fact that each poet has a different aesthetics and sensibility, a certain regularity can be identified. We can see a slow passage from the older generation's nostalgic sentiment and homesickness to the painful love for country among the young, though the subject of the motherland becomes less and less visible in Mauritian poetry.

\footnotetext{
${ }^{10}$ Jean Marc Santucci, "Midnight sunburn et les 17 pas vers l'optimisme lucide," September 15, 2017, https://koze.mu/decouvrir/bouillon-kiltir/lisa-ducasse-midnight-sunburn/

${ }^{11}$ Sylvestre Le Bon, "Les chemins de feu," in Anthologie de la poésie Mauricienne contemporaine d'expression Française, edited by Yusuf Kadel (Paris: Acoria, 2014), 92.

${ }^{12}$ Cf. Jarosz, "Brzmienie tęczy," 156.

${ }^{13}$ Umar Timol, La Parole Testament suivi de Chimie (Paris: L'Harmattan, 2003), 78-79.
} 


\section{Back to the Roots?}

Postcolonialism is not the main subject of my research, but ignoring the fact that many Mauritians have suffered from this unfair regime would certainly distort the view of their identity. Nearly four centuries of colonial rule (1598-1968) have incontestably shaped the island, on the one hand developing its culture and providing order, on the other - supporting social inequality (the condition of slaves and indentured labourers) and imposing a certain way of thinking. It takes many years for a nation to relieve itself of this burden, even after the collapse of the colonial system. Perhaps this is why some poets show an inclination towards martyrology, reliving the tragic fate of their ancestors. Jarosz called this phenonomenon "a martyrological postmemory,"14 probably having in mind the developed definition of postmemory proposed by Marianne Hirsh: "The relationship that later generations or distant contemporary witnesses bear to the personal, collective, and cultural trauma of others - to experiences they 'remember' or know only by means of stories, images, and behaviors." 15

With regard to martyrology, we have to mention two phenomena characteristic of Mauritian reality: "marronage" - the condition of one's liberty being constantly endangered, which was the reality of the fugitives from plantations (fr. "marrons"), and "coolitude" - the status of a coolie, the poorest Indian labourer who was uprooted and forced to define a new cultural identity among strangers. The presence of these topics in a recent anthology of Mauritian poetry (2014) could be proof of the continuing need of postmemory, though this seems a domain of the older generation, and the number of such poems is limited. Effectively, Markus Arnold notes that Mauritius was part of panAfrican identification movement of the 1970s, but already in the 1980s a certain lack of interest in the subjects relevant to slavery can be observed, as well as a desire to cut ties with the servile, shameful past. According to the researcher, the absence - or avoidance - of themes concerning human trafficking, servitude, marronage or Africanity in Mauritian texts is also applicable to the next decade, with few exceptions. ${ }^{16}$ As his words accord with my remarks concerning the most recent poetry, I am not going to develop this topic. Instead, let us compare two examples of reference to the disturbing past and juxtapose them with a few verses written by a young poetess.

Maunick's Épitaphe sans haine (Epitaph without hatred) could be ranked as an emblematic Mauritian poem concerning the struggle of Black people for freedom and other human rights. Maunick, as a métis who considered himself "preferentially black," fights for the development of African culture; starting by deploring the murder of an African American activist, Medgar Evers, he proceeds to more general reflections about the condition of Black people.

Original text

$[\ldots]$

Toujours ce rêve nègre lancé comme un cri Jamais personne sa rumeur ne pourra vaincre
Philological translation

$[\ldots]$

Always this black dream cast like a cry

No one ever his rumour won't be able to defeat

\footnotetext{
${ }^{14}$ Cf. Jarosz, "Brzmienie tęczy," 157.

${ }^{15}$ Marianne Hirsh, Connective Histories in Vulnerable Times, Presidential Address (Modern Language Association convention, 2014), 339.

${ }^{16}$ Cf. Markus Arnold, La littérature mauricienne contemporaine (Berlin: Lit Verlag, 2017), 129-130.

${ }^{17}$ Edouard Maunick, "Épitaphe sans haine," in Anthologie de la poésie Mauricienne contemporaine d'expression Française, ed. Yusuf Kadel (Paris: Acoria, 2014), 109.
} 
Infiniment féroce le désir d'être un homme Parmi les hommes !

[...]

Il croyait qu'on était tous créés à l'image de

Dieu

Il l'avait entendu au catéchisme

C'est écrit sur la page blanche

En caractères noirs

Alors il a cru... ${ }^{17}$
Infinitely ferocious the desire to be a man

Among men !

[...]

He believed we were all made in the image of

God

He had heard that in Sunday school

It is written on a white page

With black letters

So he believed...

The second passage is by Khal Torabully, a 63-year-old poet and academic who coined the concept of coolitude in 1992. This concept seems particularly interesting in the context of migration and the quest for identity, and, considering the concept's complexity and multidimensionality, it would be best to look at it from the perspective of the author himself:

Coolitude posits an encounter, an exchange of histories, of poetics or visions of the world, between those of African and of Indian descent, without excluding other sources. In the broadest sense the coolie was a labour migrant without the word of his Voyage [...] Viewed from this angle, coolitude does redefine the concept of indianite when it is a fixist set of 'Indian' values, leading to the acceptance of the presence of other cultural facets. Coolitude also seeks to emphasize the community of visions between the slave and the indentured labourer, shared by their descendants, despite the fact that these two groups, were placed in a situation of competition and conflict. ${ }^{18}$

But at the heart of coolitude, there is a view that the 'Indian migrant' should become part and parcel of an identity open to the dynamics of cultural interplay. ${ }^{19}$

Torabully uses the concept not only in academic debates, but also in his artistic creation, which accords more personal and emotional value to such an abstract notion. His Coolitude aux méridiens (Coolitude on the meridians) is a poem which depicts the coolie status and his ancestors' journey to the land of new hopes and expectations, far away from "sunny India." The images of sea and travels are quite frequent in Mauritian literature, but not necessarily in the context of sea voyage, as in this passage:

Original text

île mienne, il faut mettre

la terre en prémonition

et retracer les contours

de la carte bleue du voyage.

Là-bas,

L'Inde et le soleil dominent les yeux rouges des araignées.

Terre natale accrochée au fil de mes rêves tissés et retissés, réticents? ${ }^{20}$
Philological translation

my island, we have to set up

the land on premonition

and retrace the contour

of the credit card of the journey.

There

India and sun dominate the red eyes of the spiders

Motherland tied to the thread of my woven and rewoven dreams unwilling?

\footnotetext{
${ }^{18}$ Marine Carter, Khal Torabully, Coolitude: An Anthology of the Indian Labour Diaspora (London: Anthem Press, 2002), 150.

${ }^{19}$ Ibid, 148.

${ }^{20}$ Khal Torabully, "Coolitude aux méridiens," in Anthologie de la poésie Mauricienne contemporaine d'expression Française, ed. Yusuf Kadel (Paris: Acoria, 2014), 147.
} 
Coolies and Creoles were given their own narration then; Maunick and Torabully are the only "old" authors contributing to the recent anthology. In this case, the question arises as to the attitude of the youth towards postcolonial matters. Surprisingly or not, it appears that the atrocities of colonial society were not affecting enough to warrant writing about them; either way, it is hard to find any reference to postcolonialism in the most recent poetry. It is seemingly preferred to pass over such complex topics in order to focus on tiny pieces of the social puzzle, small enough to grasp in one short poem. Instead of dredging up the past, the avant-garde of Mauritian poetry would rather have a fresh start. This is not a generation concerned about their sort of being descendants of slaves and labourers. On the contrary, these few young poets are willing to become global citizens, using their talents as well as their formative and multicultural experiences to influence literature, and not only the literature of the Indian Ocean, but also that of the English or French. What is more, they tend to question stereotypes, such as the one about mystical India, from where they mostly came:

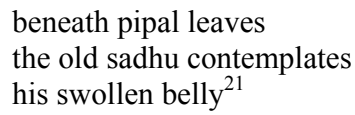

As we can see, Arjanee derides the concept of mystical land left by her forefathers. A swollen belly, a symbol of starvation, does not seem an object fit for contemplating, even by a religious ascetic who has renounced worldly life. Arjanee's India is neither mysterious nor desirable. It appears as just a country worth visiting, without Arjanee being too sentimental about it.

\section{Migration}

Does this mean then that young poets do not bother themselves with topics related to migration either? In fact, their poetry is often so immersed in the inner world of sensations, feelings and dreams that social issues are less visible. Let us compare two poems to illustrate this difference. The first one is written by Maunick, who spent a great part of his life in Paris:

Original text

Partir comme on jette les dés Au bout de la nuit-solitude Partir pour briser l'habitude D'entendre ton absence gronder De cent fois lire les mêmes lettres De cent fois dire tu vas renaître
Philological translation

Leave like one throws the dice At the end of the solitude-night Leave to break the habit To hear your absence rumble

To read a hundred times the same letters To say a hundred times you will reborn ${ }^{22}$

Maunick has had a long experience of expatriation, as well as being a stranger both to white and black people, therefore his poetry reflects real loneliness and rejection. He deems himself a "forever nomad," 23 at times sorry for having deserted his motherland, at times troubled by the "tyranny of the first country." 24 His poems arouse feelings

\footnotetext{
${ }^{21}$ Arjanee, Morning with my Twin Sister, 70.

${ }^{22}$ Edouard Maunick, "Guitare ballade," in Anthologie de la poésie Mauricienne contemporaine d'expression Française, edited by Yusuf Kadel (Paris: Acoria, 2014), 116.

23 “à jamais nomade," Maunick, "Elle," 106.

24 "la tyrannie du pays premier / me trouble autant au seuil du grand âge." Ibid.
} 
through a parsimonious portrayal of actions and situations related to emigration. Arjanee has also written a poem entitled Immigrant, but its message is quite different. She describes a scene at the airport with her dead grandfather playing the role of a ticket controller:

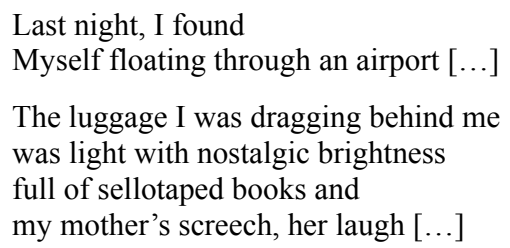

There was my grandfather, who had long since (since when?) packed his smile in a coffin and taken flight one quiet morning in Mauritius

He was there (again), he was suntanned, wearing an officer's uniform with a blurred name tag

His gentle hands stapled my tickets gave them back to me Smiling at me (again) a smile which was oddly distant, he said in a voice ephemeral as sunshine:

"Best of luck"

and moved away, to let me take a ghost-heart step through those white styrofoam doors retracting like a breathing uterus

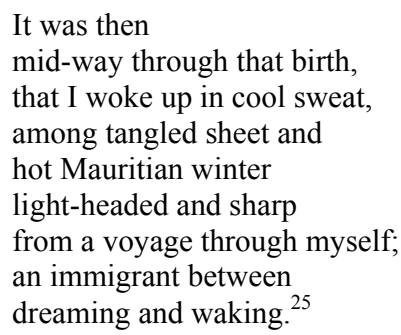

Migration is here internalized, not necessarily connected with any spatial movement. One may even be even tempted to compare Arjanee's migration to death and crossing to the other side. In any case, this migration is surely a state of mind and not a matter of any geographical position.

And that, precisely, is the case of the rising generation. For the young poets who study abroad - Gopee in the USA, L. Ducasse in France and Arjanee in Spain a chance to travel around the world is more an adventure than a sad necessity. Thanks to modern technology and social media, they are never really cut off from their motherland unless they choose to be. It is unlikely to spot any sign of homesickness in their poetry, nor do they appear to be tied to their homes. Of course, in general terms,

\footnotetext{
${ }^{25}$ Arjanee, Morning with my Twin Sister, 102-104.
} 
they are familiar with migration and its consequences, one example being that the refugees' plights arouse their sympathy. Still, as long as they are not personally concerned, the lack of a need to discuss the subject seems quite comprehensible.

Why is there no mention of the "middle" generation here? Mostly because they have not emigrated from Mauritius, except for leaving temporarily for their studies. The majority foster a favourable environment for the artists living on the Island by creating a literary magazine Point Barre, for instance (the initiative of Kadel, supported mainly by Jacquin-Ng and Timol), or by helping to promote young authors (Samboo who translated Arjanee's poems into French or M. Ducasse who is the first literary critic of his daughter, Lisa). The middle generation more interested in portraying the Island, both landscapes and people, and seem to concentrate on the current problems of their multicultural society.

\section{Conclusion}

Returning to our central question: how to be a nation of migrants? Surprisingly, the Mauritian answer to such a complex reality proves to be rather simple: to live and to let live. In the rich and polyphonic poetry of Mauritius there is a place for solemn postmemory and a place for sarcastic comments. The poets of the Paradise Island are a curious mixture of patriots concerned about their country and young optimists who become a part of the global village with all the advantages and drawbacks of such a decision. Some of them feel the need to face the legacy of the colonial past, while for others it is more important to be grateful for the opportunities of the present day. It needs to be noted that the three generations described herein are somehow complementary and respectful to each other. The best example are the fully-fledged authors who encourage their successors from the rising generation and help them promulgate their poetry collections. The rift between global citizens and postcolonial patriots seems then wide enough to mark the new poetical trend resulting from the social changes, but does not imply a total rupture with the past.

\section{BIBLIOGRAPHY}

Arnold, Markus. La littérature mauricienne contemporaine. Berlin: Lit Verlag, 2017.

Arjanee, Ameerah. Morning with my Twin Sister and other poems. Trou d'Eau Douce: L'Atelier d'écriture, 2014.

Carter, Marine, and Khal Torabully. Coolitude: An Anthology of the Indian Labour Diaspora. London: Anthem Press, 2002.

Hirsch, Marianne. Connective histories in vulnerable times. Presidential Address at Modern Language Association convention (2014): 330-348. https://apps.mla.org/pdf/2014_pres address_pmla.pdf.

Jarosz, Krzysztof. "Brzmienie tęczy. O współczesnej francuskojęzycznej poezji Mauritiusa." Opcje 3 (2016): 152-157.

Joubert, Jean-Louis. Littératures de l'océan Indien. Paris: Vanves, 1991.

Joubert, Jean-Louis. "La poésie mauricienne d'aujourd'hui." Francofonia 48 (2005): 125-132.

Kadel, Yusuf, ed. Anthologie de la poésie Mauricienne contemporaine d'expression Française. Paris: Acoria, 2014.

Prosper, Jean-Georges. Histoire de la littérature mauricienne de langue française. Port-Louis: Éditions de l'Océan Indien, 1994.

Santucci, Jean Marc. "Midnight sunburn et les 17 pas vers l'optimisme lucide." Kozé. Zigzag kiltirel. September 15, 2017, https://koze.mu/decouvrir/bouillon-kiltir/lisa-ducasse-midnightsunburn/. 
Timol, Umar. La Parole Testament suivi de Chimie. Paris: L'Harmattan, 2003.

Szkonter-Bochniak, Anna. L'analyse des personnages principaux dans les romans d'Ananda Devi a la lumière du modèle théorique de l'effet-personnage de Vincent Jouve. Praca doktorska. Katowice: Uniwersytet Śląski, 2018.

Ramharai, Vicram. "Le champ littéraire mauricien." Revue de littérature comparée, (avril-juin 2006): 173-194.

Ramharai, Vicram. "Entre littérature mauricienne et littérature francophone : quels enjeux pour les écrivains mauriciens?" E-France: an on-line Journal of French Studies 2 (2008), https://www.reading.ac.uk/web/files/e-france/Ramharai.pdf.

\section{HOW TO BE A NATION OF MIGRANTS? A RETURN TO ROOTS VERSUS GLOBAL CITIZENSHIP IN CONTEMPORARY MAURITIAN POETRY}

The purpose of this article is to present the contemporary literary tendencies concerning the national and migrant identity in the Mauritian poetry written in the second half of $20^{\text {th }}$ century and in the $21^{\text {st }}$ century. The analysis of chosen poems aims to show the principal currents and outline different attitudes of the older and the rising generations of poets. Firstly, the Author describes briefly the history of literature in Mauritius, an island in the Indian Ocean which has become a homeland for French colonizers, African slaves, Indian coolies and Chinese indentured labourers. As the literature was born in the French-speaking Creole circles, the poetry remains primarily francophone, though a significant part of younger generation chooses to express themselves in English. There is a broad range of authors whose attempts to find or define their identity are reflected in their poetry, because the theme of problematic migrant condition is apparently crucial for Mauritians. There are some who confront the colonial past and fight racism, others tend to concentrate on the present day, trying to fit in the multicultural society and cope with the difficulties of multilingualism. The youngest become global citizens, writing in English about universal human experiences. The Author describes the differences between these three groups, concentrating on three dimensions of Mauritian identity: motherland, migration and postcolonialism. Apparently, the rising generation does not totally break the ties with their homeland, but grows independent. Mauritian origins influence their creation a lot less, comparing to the older authors. On the contrary, the generation born in 1960s and 1970s often address social issues, relevant either to the postcolonialism or to the problems of modern society. Among oldest poets who emigrated to France it is the lyrical and nostalgic tone that prevails, whereas the youngest, despite leaving their island at least for the time of studies, are definitely more critical and distant, if they write about Mauritius at all. In conclusion, it seems that there is a visible passage from the topics directly related to the Island in favour of more personal and more universal poems.

KEY WORDS: Mauritius, contemporary poetry, identity, migration, global citizenship

\section{JAK BYĆ NARODEM MIGRANTÓW? POWRÓT DO KORZENI VERSUS GLOBALNE OBYWATELSTWO WE WSPÓLCZESNEJ POEZJI MAURYTYJSKIEJ}

Celem artykułu jest przedstawienie współczesnych tendencji literackich związanych $\mathrm{z}$ tożsamością narodową oraz migracją w poezji maurytyjskiej publikowanej w drugiej połowie XX wieku oraz w wieku XXI. Analiza wybranych wierszy ma na celu ukazanie głównych nurtów poetyckich i podkreślenie różnic pomiędzy narracją starszego i młodszego pokolenia poetów. W pierwszej kolejności Autorka opisuje pobieżnie historię literatury Mauritiusu, wyspy położonej na Oceanie Indyjskim, która stała się domem dla europejskich kolonizatorów, afrykańskich niewolników, indyjskich kulisów oraz kontraktowych robotników z Chin. Jako że pierwsze dzieła literackie powstały w środowiskach zamożnych Kreolów mówiących po francusku, poezja maurytyjska pozostaje tradycyjnie francuskojęzyczna, chociaż obecnie znacząca część młodszego pokolenia publikuje w języku angielskim. Próby odnalezienia bądź zdefiniowania własnej tożsamości znajdują odzwierciedlenie w wielu utworach współczesnych maurytyjskich poetów. 
Część z nich stawia czoła kolonialnej przeszłości i walczy z rasizmem, inni wola skupić się na chwili obecnej, starając się odnaleźć w wielokulturowym społeczeństwie i poradzić sobie z własną wielojęzycznością. Najmłodsi stają się kosmopolitami piszącymi po angielsku o powszechnych ludzkich doświadczeniach. Autorka opisuje różnice pomiędzy tymi trzema grupami przez pryzmat trzech wymiarów maurytyjskiej tożsamości: stosunku do ojczyzny, do migracji oraz do postkolonializmu. Młode pokolenie nie zrywa całkowicie więzów z ojczystą wyspą, ale zdecydowanie się uniezależnia. Korzenie maurytyjskie w dużo mniejszym stopniu wpływają na charakter ich twórczości niż ma to miejsce w przypadku starszych autorów. W przeciwieństwie do nich, pokolenie urodzone w latach 1960-1970 często porusza kwestie społeczne, czy to związane $\mathrm{z}$ postkolonializmem, czy to z wyzwaniami nowoczesnego społeczeństwa. Wśród najstarszych autorów, z których wielu wyemigrowało do Francji, dominuje nastrój nostalgiczno-liryczny, podczas gdy młodsi, mimo opuszczenia rodzinnej wyspy przynajmniej na czas studiów, podchodzą do niej zdecydowanie bardziej krytycznie i z dystansem, o ile w ogóle poświęcają jej miejsce we własnych poetyckich poszukiwaniach. Na podstawie analizy można wysnuć wniosek o wyraźnym przesunięciu tematycznym, polegającym na odejściu od problematyki maurytyjskiej na korzyść wierszy bardziej osobistych i uniwersalnych.

SŁOWA KLUCZOWE: Mauritius, współczesna poezja, tożsamość, migracja, globalne obywatelstwo 